\title{
Aloysio de Castro and Uruguay
}

\section{Aloysio de Castro e Uruguai}

\author{
Eduardo Wilson
}

\begin{abstract}
Aloysio de Castro, when Director of the School of Medicine of Rio de Janeiro, and Américo Ricaldoni, when Dean of the School of Medicine of Montevideo, Uruguay, started a period of intense collaboration between both institutions. In this period, Aloysio visited Montevideo in many occasions, giving lectures, donating scientific material and publishing papers in Uruguay. Ricaldoni retributed his visits, distinguishing Aloysio as the first foreign Honorary Professor of the Medical School of Uruguay, participating in the inauguration of the new building of the School in Rio. Even after Ricaldoni's death in 1928, for many years, Aloysio continued with his visits. A poem by Aloysio de Castro dedicated to Montevideo is attached.
\end{abstract}

Keywords: Aloysio de Castro, Américo Ricaldoni, Uruguay, neurohistory.

\section{RESUMO}

Aloysio de Castro, sendo Diretor da Faculdade de Medicina do Rio de Janeiro, e Américo Ricaldoni, como Decano da Faculdade de Medicina de Montevidéu, Uruguai, começaram um período de estreita colaboração entre as duas instituições. Nesse então, Aloysio visitou Montevidéu várias vezes, dando palestras, doando material científico e publicando artigos no Uruguai. Ricaldoni retribuiu as suas visitas distinguindo ao Aloysio como o primeiro Professor Honorário estrangeiro da Faculdade de Medicina, e participando na inauguração do novo edifício da Faculdade no Rio. Após a morte de Ricaldoni, em 1928, Aloysio continuou com as suas visitas. Anexa-se um poema do Aloysio de Castro dedicado à Montevidéu.

Palavras-chave: Aloysio de Castro, Américo Ricaldoni, Uruguai, neurohistória.

In September 1916, while assisting to the first National Medical Congress of Argentina in Buenos Aires, the Brazilian physician Aloysio de Castro (1881-1959) met Américo Ricaldoni (1867-1928) of Uruguay. ln spite of his short age, 35 years, Aloysio (Figure 1) already was Professor of Clinical Medicine and Director of the School of Medicine of Rio de Janeiro. 47 year old Ricaldoni (Figure 2), was also Professor of Clinical Medicine and Dean of the Uruguayan School of Medicine.

Ricaldoni, who was very proud of the new building of his School of Medicine, inaugurated 4 years before (Figure 3), convinced Aloysio to visit it on his way back home to Rio. The invitation was accepted, and on September 29, Aloysio de Castro arrived at Montevideo for the first time. In the company of the Dean, counselors and teachers, Aloysio went through the different premises of the new building, made laudatory comments and finally participated in a ceremonial reception at the deanery (Figure 4), in the course of which Ricaldoni expressed his admiration for the multifaceted personality of the visitor ${ }^{1}$.

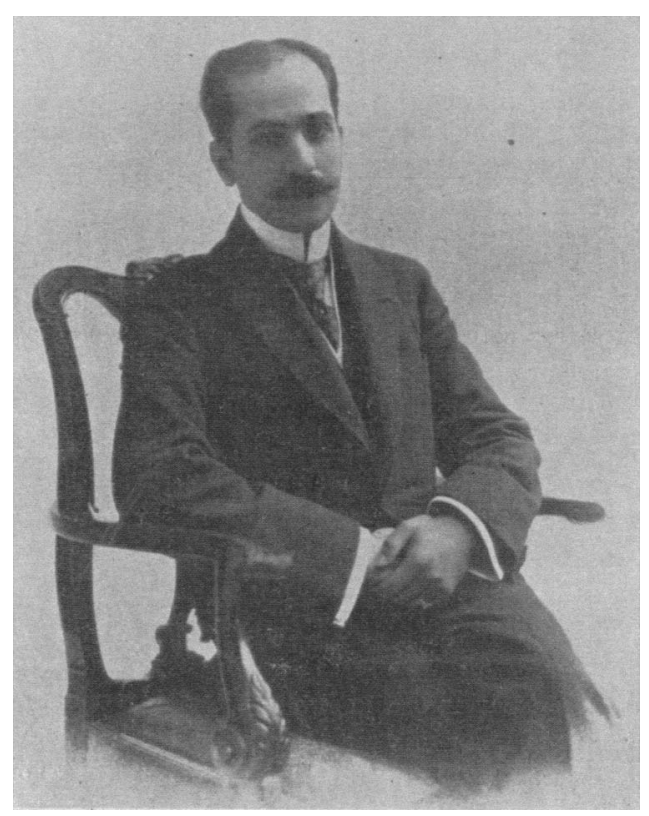

Figure 1. Aloysio de Castro. 


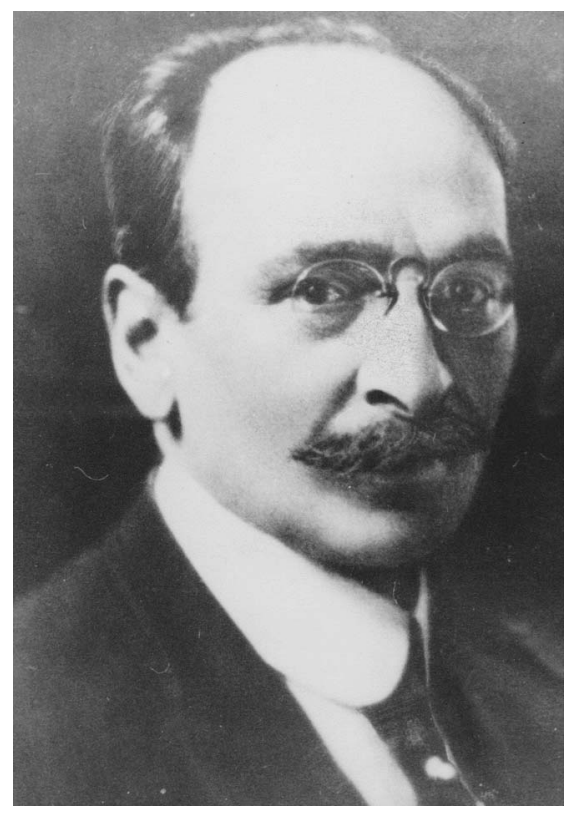

Figure 2. Américo Ricaldoni.

During the following months Ricaldoni received many telegrams of gratitude and a long letter informing that the professors of Rio had approved the strengthening of the academic ties between both institutions, and inviting Ricaldoni to visit them at Rio once the new building was finished (Figure 5).

In January 1917 Aloysio de Castro was distinguished as Honorary Professor of the School of Medicine of Montevideo. This was the first time this distinction was awarded to a foreigner. And in the second volume of Anales de la Facultad de Medicina de Montevideo, corresponding to 1917, an article by Aloysio on Millard-Gubler syndrome of traumatic origin was published ${ }^{2}$.

One year later, in 1918, Aloysio sent a donation of 22 wax models reproducing in natural size lesions observed in cases of the Dermatological Clinic. Soon after, between March 26

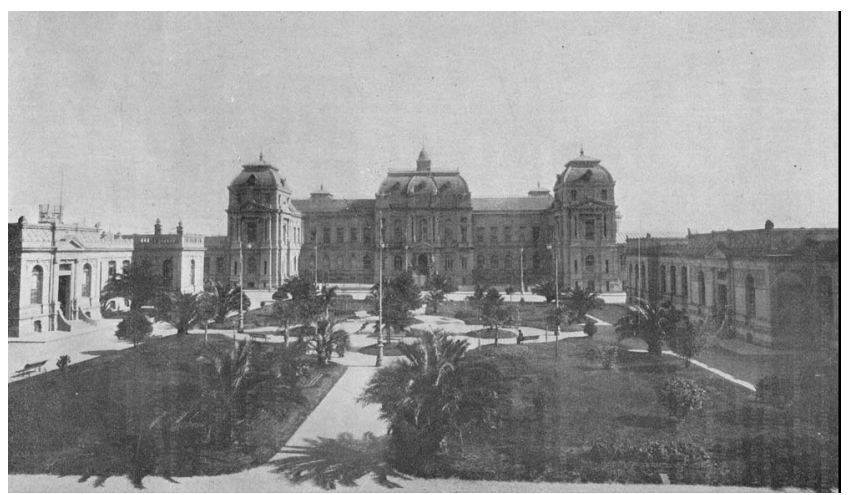

Figure 3. Building of the School of Medicine of Montevideo inaugurated in 1911.

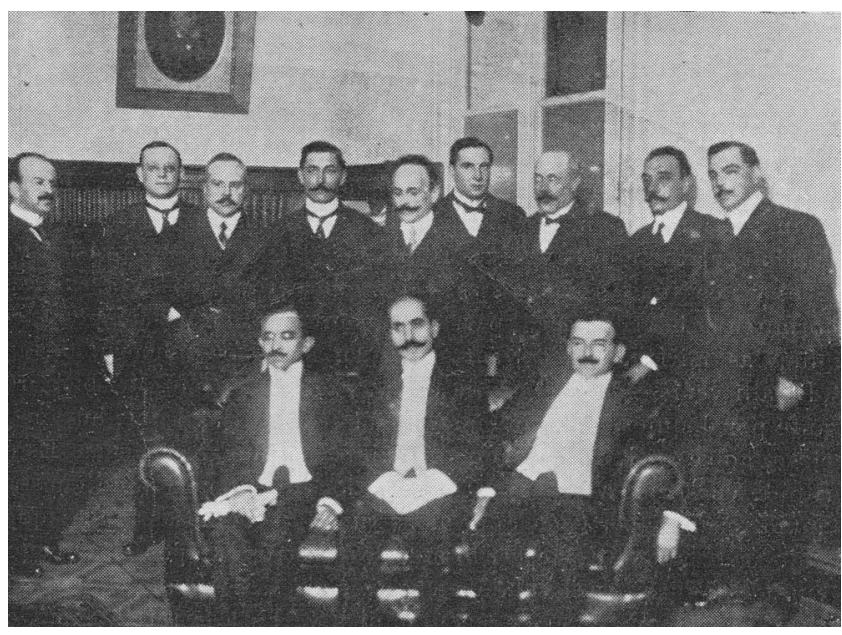

Figure 4. Reception in honour of Aloysio de Castro, September 1916, at Montevideo. Seated are the visitors from Brazil: Bruno Lobo, Aloysio de Castro, Thompson Motta. Américo Ricaldoni is standing behind Aloysio.

and April 2, he returned to Montevideo and gave two lectures, entitled "The system of paraglandular organs", published in Anales ${ }^{3}$ and "Various cases of neuropathology". This last lecture included a film exhibition of the cases. He also made a new donation, this time of anatomical specimens.

In October 1918 Ricaldoni returned Aloysio's visit, and participated in the $8^{\text {th }}$ National Medical Congress of Brazil and in the ceremony of inauguration of the new School of Medicine of Rio de Janeiro, speaking in the name of the many visitors come from abroad. A few years later, another of his papers was published in Uruguay ${ }^{4}$.

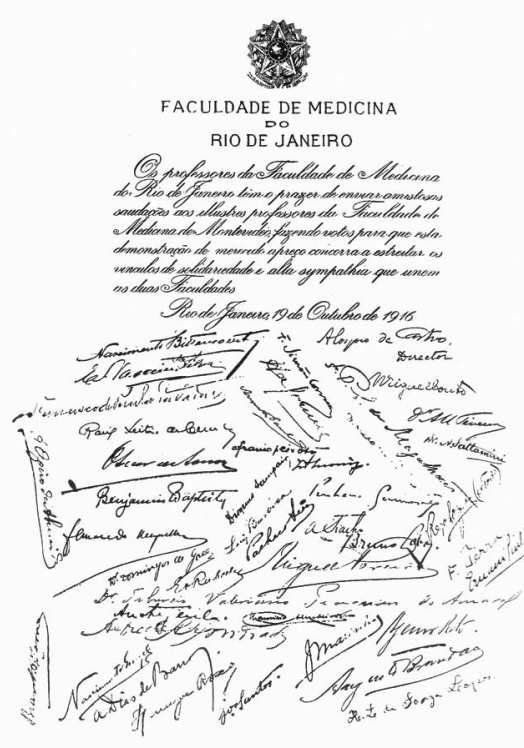

Figure 5. Letter from the professors of the Faculdade de Medicina de Rio de Janeiro addressed to Américo Ricaldoni. 
When the School of Medicine of Montevideo decided it was time to create a Chair of Nervous Diseases, Américo Ricaldoni was the natural candidate, for as his friend Aloysio de Castro, he had always favored teaching semiology of the nervous system and treating neurological patients. As chairman of Nervous Diseases, he immediately pursued the creation of a Neurological Institute, which should include basic and clinical investigation, special studies of patients and adequate treatment, including neurosurgery. Finally, in 1926 a law was passed creating the Instituto de Neurología, first institution of its kind in Latin America, and Ricaldoni was appointed its first Director. In May 1927 the Instituto de Neurología de Montevideo opened its doors at the Hospital Maciel. Ricaldoni knew he was dying because of a mortal disease of his larynx, but he was obsessed with the publication of the Anales del Instituto de Neurología, which he had just created. His last efforts were dedicated to this task, and the publication appeared a few days before his death in $1928^{1}$. In this first volume, an article form his friend Aloysio could not be absent. To avoid delays, after receiving it, he personally translated it into Spanish. This paper of Aloysio de Castro deals with cutaneous reflexes ${ }^{5}$.

Apart from the above mentioned visits to Montevideo, Aloysio de Castro continued coming to Uruguay. After Ricaldoni's death, Aloysio returned in 1934, 1936, 1938 and 1941. In 1936 he lectured on the modern anatomo-clinical concept of cerebral hemorrhage ${ }^{6}$; in 1941 he participated in the Second Panamerican Child Congress. Due to his friendship with Ricaldoni's successor, Alejandro Schroeder, he maintained the close relations with Uruguayan medicine and particularly with the Instituto de Neurología.

Juan Pou Orfila, Uruguayan professor of Obstetrics, remembered having visited Aloysio's home in Rio, where he found a gallery of photographs of his many friends, among which were pictures of Uruguayans: Américo Ricaldoni, Luis Morquio, Manuel Quintela, José Scoseria and the poet Juana de Ibarbourou?

Aloysio de Castro has been the foreign Honorary Professor of the School of Medicine of Montevideo that most participated in academic activities. His brilliant intellect, his condition of representative of Brazilian science and art, and his friendship with Ricaldoni, originated in their common interest in Neurology, made him a referential personality for Uruguayan medicine and especially for Uruguayan neurology.

As a token of friendship to our country, making use of his poetic inspiration, Aloysio de Castro composed a poem titled "Montevideo", which runs as follows (p.23-4):

Montevideo

Terra de encantos, que entre o mar e o rio

estendes tuas praias.

Outros cantem teus fastos, tuas glorias,

teus héroes, teu pasado.

Eu louvarei somente a amena graça

da tua natureza,

teus parques ensombrados onde á noite

chega um eco da flauta

que adormece nos campos os rebanhos,

teus jardins olorosos

e as multicores rosas de Novembro.

Cantarei teu sorriso

de luz, o claro esmalte do teu ceo,

e a belleza suprema,

a flor da alma gentil de tua gente

Montevideo, Montevideo!

\section{References}

1. Wilson E, Mañé-Garzón F. Américo Ricaldoni: artífice de la medicina uruguaya. Montevideo: Ediciones de la Plaza; 2009. (Colección Biografias).

2. Castro A. Síndrome de Millard Gubler de origen traumático. An Fac Med Montevideo. 1917;2:697-711.

3. Castro A. O sistema dos organs para-glandulares. An Fac Med Montevideo. 1918;3:269-94.

4. Castro A. Os ensaios operatorios de rejuvenescimento orgánico e a therapéutica da dystrophia genito-glandular. An Fac Med Montevideo. 1921:6:233-54.
5.

Castro A. O moderno conceito anatomo-clinico da hemorragia cerebral. An Fac Med Montevideo. 1937;22:1-12.

7. Pou-Orfila J. Un brasileño ilustre, el profesor Aloysio de Castro, grande amigo del Uruguay. Publicaciones Instituto de Cultura Uruguayo-Brasileño. 1944,4:5-24. 